\title{
Extracorporalis membránoxigenizáció intenzív osztályon
}

\author{
14 eset ismertetése
}

\author{
Zöllei Éva dr. ${ }^{1}$ - Bari Gábor dr. ${ }^{2}$ - Blaskovics Ivett dr. ${ }^{3,4}$ \\ Bodó Kinga dr. ${ }^{1}$ - Csorba Zsófia dr. ${ }^{1}$ - Hankovszky Péter dr. ${ }^{1}$ \\ Korsós Anita dr. ${ }^{1}$ - Lovas András dr. ${ }^{1}$. Szabó-Biczók Antal dr. ${ }^{2}$ \\ Babik Barna dr. ${ }^{1}$. Molnár Zsolt dr. ${ }^{5,6}$. Rudas László dr. ${ }^{1}$ \\ 'Szegedi Tudományegyetem, Általános Orvostudományi Kar, \\ Aneszteziológiai és Intenzív Terápiás Intézet, Szeged \\ ${ }^{2}$ Szegedi Tudományegyetem, Általános Orvostudományi Kar, Kardiológiai Központ, Szívsebészeti Osztály, Szeged \\ ${ }^{3}$ Szegedi Tudományegyetem, Általános Orvostudományi Kar, Sebészeti Mútéttani Intézet, Szeged \\ ${ }^{4}$ Gottsegen György Országos Kardiovaszkuláris Intézet, Budapest \\ ${ }^{5}$ Pécsi Tudományegyetem, Transzlációs Medicina Intézet, Pécs \\ ${ }^{6}$ Poznan University of Medical Sciences, Department of Anaesthesiology and Intensive Therapy, \\ Poznan, Lengyelország
}

\begin{abstract}
Az extracorporalis membránoxigenizációt egyre gyakrabban alkalmazzák világszerte refrakter légzési és/vagy keringési elégtelenség kezelésében. Intézetünkben 2015-ben kezdtük meg a program előkészítését és felépítését. Célunk az extracorporalis membránoxigenizációs kezelés élettani alapjainak rövid ismertetése, különös tekintettel a venovenosus konfigurációra, és az eddig kezelt eseteink eredményeinek összefoglalása. Az irodalom szisztematikus áttekintése és a kezelt esetek adatainak retrospektív értékelése voltak a módszereink. 2016 óta összesen 14 beteg esetében használtunk extracorporalis membránoxigenizációt ( 8 férfi, 6 nő, életkor $51 \pm 15$ év, APACHE II. score $24 \pm 7$ ). Az indikáció 9 esetben súlyos refrakter hypoxaemiás légzési elégtelenség, 1 esetben tracheooesophagealis fistula és légzési elégtelenség, l esetben műtét alatti támogatás tervezett trachearekonstrukció során és 3 beteg esetében refrakter cardiogen shock volt. Az extracorporalis membránoxigenizáció 11 betegben a légzés, 3 betegben a keringés támogatását szolgálta, 13 venovenosus, 1 venoarteriosus konfigurációban. Az extracorporalis támogatás ideje légzéstámogatás esetében $14 \pm 6$ nap, a cardialis támogatások esetében $5 \pm 4$ nap volt. Az intenzív osztályos ápolási idő $27 \pm 13$, illetve $21 \pm 17$ nap volt a két betegcsoportban. 9 beteget jó funkcionális állapotban bocsátottunk el, 5 beteg halt meg osztályunkon, további 3 később a kórházi bennfekvés során. Az extracorporalis membránoxigenizációs program regionális centrumokban Magyarországon is megvalósítható. A nemzetközi ajánlások, oktatási módszerek alkalmazásával a nemzetközi irodalomban közölt túlélési eredményekhez hasonló eredmények érhetők el hazánkban is. Orv Hetil. 2021; 162(11): 425-431.
\end{abstract}

Kulcsszavak: extracorporalis membránoxigenizáció, légzési elégtelenség, intenzív kezelés

\section{Extracorporeal membrane oxygenation in intensive care unit}

\section{Case series of 14 patients}

Extracorporeal membrane oxygenisation is commonly used worldwide for refractory respiratory and circulatory failure. We started to organise the introduction of this therapeutic modality in 2015. Our aim is to give a short review about extracorporeal life support, especially veno-venous extracorporeal membrane oxygenation, and to present our first results. We provide a systematic review of the currently available literature and a summary of our first treatments. As of 2016, we supported 14 patients with extracorporeal membrane oxygenisation $(8 \mathrm{men}$, age $51 \pm 15$ years, APACHE II score $24 \pm 7$ ). The indications were refractory hypoxaemic respiratory failure in 9 , tracheo-oesophageal fistula and respiratory failure in 1 , support during surgery for planned tracheal reconstruction in 1 , and refractory cardiogenic shock in 3 patients. We provided respiratory support in 11 , circulatory support in 3 cases, with 13 venovenous and 1 veno-arterial configuration. The support lasted for $14 \pm 6$ days in respiratory, and for $5 \pm 4$ days in cardiac cases. Intensive care length of stay was $27 \pm 13$ and $21 \pm 17$ days in the two patient groups. We discharged 
9 patients in good functional state, 5 patients died during intensive care and further 3 later, during the hospital stay. Our results show that the implementation of an extracoporeal membrane oxygenation program is feasible in Hungarian tertiary centers. In line with international recommendations and adapting international training courses, the survival is very similar to that reported in the literature.

Keywords: extracorporeal membrane oxygenation, respiratory insufficiency, intensive therapy

Zöllei É, Bari G, Blaskovics I, Bodó K, Csorba Zs, Hankovszky P, Korsós A, Lovas A, Szabó-Biczók A, Babik B, Molnár Zs, Rudas L. [Extracorporeal membrane oxygenation in intensive care unit. Case series of 14 patients]. Orv Hetil. 2021; 162(11): 425-431.

(Beérkezett: 2020. augusztus 10.; elfogadva: 2020. október 8.)

\begin{abstract}
Rövidítések
ACT $=$ (activated clotting time $)$ aktivált alvadási idő; APACHE $=($ acute physiology and chronic health evaluation $)$ a fiziológiai és a krónikus állapot értékelésére kidolgozott osztályozási rendszer; APRV = (airway pressure release ventilation $)$ légútinyomás-felengedő lélegeztetés; ARDS = (acute respiratory distress syndrome) akut légzési distressz szindróma; CESAR = conventional ventilatory support versus extracorporeal membrane oxygenation for severe adult respiratory failure; $\mathrm{ECCO}_{2} \mathrm{R}$ $=\left(\right.$ extracorporeal $\mathrm{CO}_{2}$ removal $)$ extracorporalis szén-dioxid-eltávolítás; ECLS = (extracorporeal life support) extracorporalis keringés- és légzéstámogatási technikák; ECMO = extracorporalis membránoxigenizáció; ELSO = Extracorporeal Life Support Organization; EOLIA = ECMO to rescue lung injury in severe ARDS; $\mathrm{FiO}_{2}=$ (fraction of inspired oxygen) belégzett oxigénkoncentráció; $\mathrm{HINl}$ = a hemagglutinin l-es és a neuraminidáz 1 -es típusát tartalmazó vírus; IBW = (ideal body weight) ideális testsúly; $\mathrm{PaO}_{2}=$ parciális oxigénnyomás az artériás vérben; PEEP $=$ (positive end-expiratory pressure) pozitív kilégzésvégi nyomás; vaECMO = venoarteriosus ECMO; $\mathrm{vvECMO}=$ venovenosus ECMO
\end{abstract}

$\mathrm{Az}$ extracorporalis keringés- és légzéstámogatási technikák (ECLS: extracorporeal life support) fejlesztése az 1930-as években kezdődött. Az első klinikai alkalmazásra 1953-ban került sor egy pitvari septumdefektus sebészi zárása során. Az elkövetkező évtizedekben a technológia, a membránoxigenátor, a pumpa és a kanülálási technika jelentős fejlődésen ment át, mely alkalmassá tette arra, hogy már nemcsak szívsebészeti beavatkozások során, hanem a műtőkön kívül, az intenzív osztályokon is használhatóvá váljék. Az eljárás használatának két fó indikációs területe körvonalazódott: a súlyos, refrakter keringési elégtelenség és a súlyos, refrakter légzési elégtelenség. A keringéstámogatásra a venoarteriosus extracorporalis membránoxigenizációt (vaECMO), a légzéstámogatásra a venovenosus extracorporalis membránoxigenizációt (vvECMO) használjuk.

$\mathrm{Az}$ extracorporalis keringési rendszer fö összetevői a kanülök, a pumpa és az oxigenátor. Ez a rendszer biztosít lehetőséget a véráramlás, a nyomások és gyakran egyéb paraméterek monitorozására is. A kanülálás történhet percutan (ultrahang- és röntgenvezérléssel) vagy sebészi technikával. Mindkét esetben - attól függően, hogy milyen ECLS-modalitást kívánunk használni megfelelő méretű „kivevo”” (access) és „visszaadó” (return) kanülöket helyezünk be. A venoarteriosus konfigurációban a „kivevő” kanül a leggyakrabban valamelyik nagy vénában (vena [v.] cava inferior vagy v. cava superior) helyezkedik el a jobb pitvar közelében, a „visszaadó” kanül pedig közvetlenül az aortába juttatja az oxigenizált vért (1. ábra). A vvECMO esetében két nagy véna (a leggyakrabban a vv. femorales vagy a v. jugularis interna) általában percutan kanülálása szükséges; a vér kivétele a v. cava inferiorból vagy a v. cava superiorból, az oxigenizált vér visszaadása pedig a jobb pitvar magasságában történik (2. ábra).

A súlyos refrakter légzési elégtelenségben alkalmazott vvECMO - a kanülök méretétől és a véráramlás mértékétől függően - biztosítja mind az oxigenizációt, mind a szén-dioxid-eltávolítást, vagy csak a szén-dioxid-eltávolítást (extracorporeal $\mathrm{CO}_{2}$ removal, $\mathrm{ECCO}_{2} \mathrm{R}$ ). $\mathrm{Az}$ oxigenizációt fóként a véráramlás, a szén-dioxid-eltávolítást pedig az ún. „sweep gas”, az oxigenátoron átáramló oxigén áramlási sebességének változtatásával tudjuk befolyásolni. A beteg tüdejét vvECMO-támogatás alatt ún. nyugalmi beállításokkal lélegeztetjük (alacsony $\mathrm{FiO}_{2}$, PEEP $10-15$ vízcm, nyomástámogatás 10 vízcm, légzésszám 10/min), ezzel segítve elő a tüdőfolyamat gyógyulását [1]. A vvECMO esetében mindig van keveredés az oxigenátorból visszavezetett oxigenizált vér és a vénás rendszeren a jobb pitvarhoz visszaáramló vénás vér között, ezért ha a saját tüdőkön keresztül gázcsere nem jön létre, vagy ez minimális, akkor 100\%-os artériás oxigénszaturáció nem érhető el [2]. A megfelelő oxigenizáció biztosításához általában az aktuális saját perctérfogat 60-70\%-ának megfelelő 'pumpaflow' szükséges; a megfelelő szén-dioxid-eltávolításhoz ennél lényegesen kevesebb, 0,5-1 1/min véráramlás is elégséges megfelelő friss gáz (sweep gas) áramlása mellett. Mivel az elérhető véráramlás a pumpán keresztül foóként a kanülök átmérőjétől függ, fontos ezek méretének gondos kiválasztása.

Az irodalomban közölt első sikeres vvECMO-alkalmazások túlélői már a negyvenes éveikben járnak, viszont a beavatkozások száma a 2009-es H1Nl-járvány 


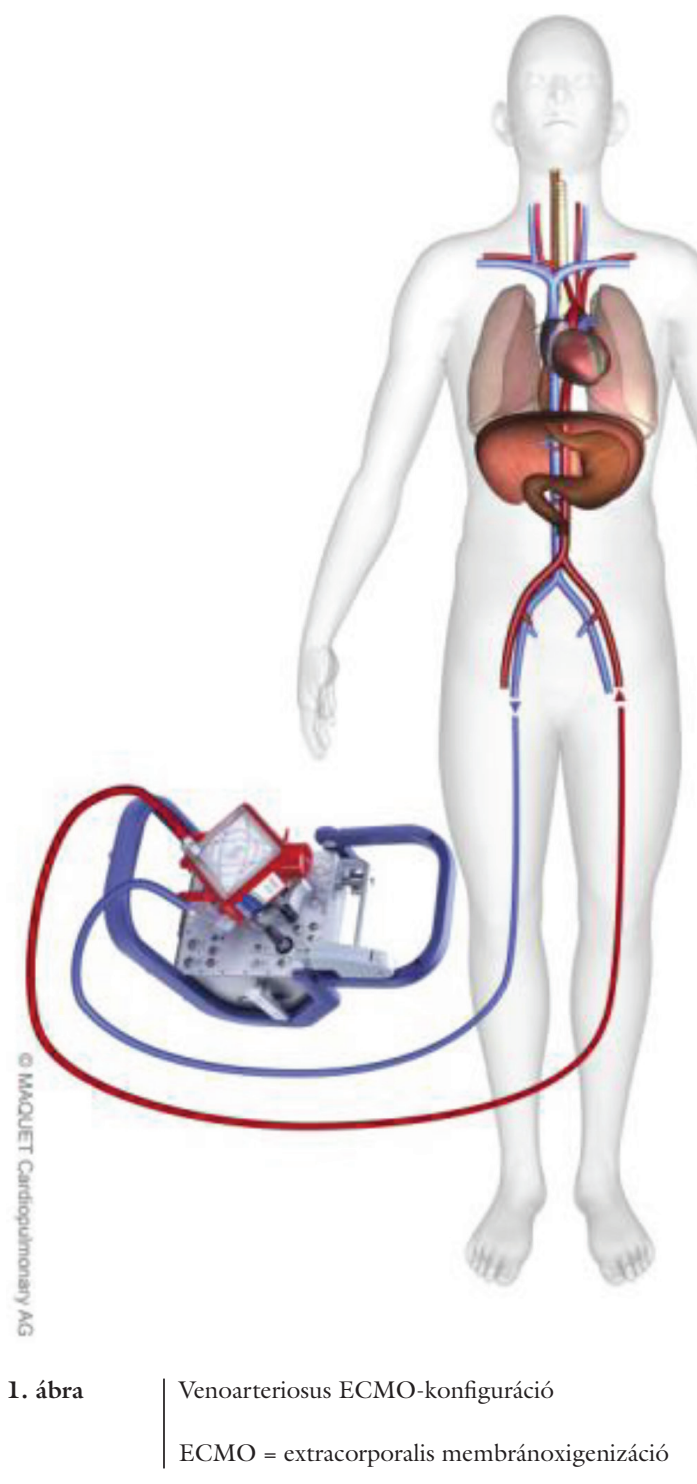

alatt és után növekedett meg jelentősen világszerte [3]. Ez több okra vezethető vissza. Egyrészt ekkor került az intenzív osztályokra nagyszámú, fiatal és gyakran kizárólag súlyos légzési elégtelenségben szenvedő beteg, akiket rendkívül eredményesen lehetett meggyógyítani ezzel a technikával [4-7]. Másrészt ebben az időben jelent meg egy nagy, multicentrikus, randomizált tanulmány (CESAR) eredménye. E szerint a súlyos hypoxaemiás légzési elégtelenségben szenvedő betegek ECMO-centrumban történő ellátása - mely szükség szerint az ECMO-alkalmazást is magában foglalta - jelentősen jobb, jó életminőséggel való 6 hónapos túlélést eredményezett az optimális hagyományos ellátáshoz képest [8]. Harmadrészt a technológia az utóbbi években olyan nagy mértékü fejlődésen ment át, mely a szövődmények számát jelentősen csökkentette, és magát a beavatkozást lényegesen egyszerúbbé tette. 2018-ban súlyos ARDSben újabb multicentrikus randomizált vizsgálat (EOLIA) eredményei váltak ismertté. Ennek alapján a korai vvECMO-kezelés a konvencionális ellátáshoz képest

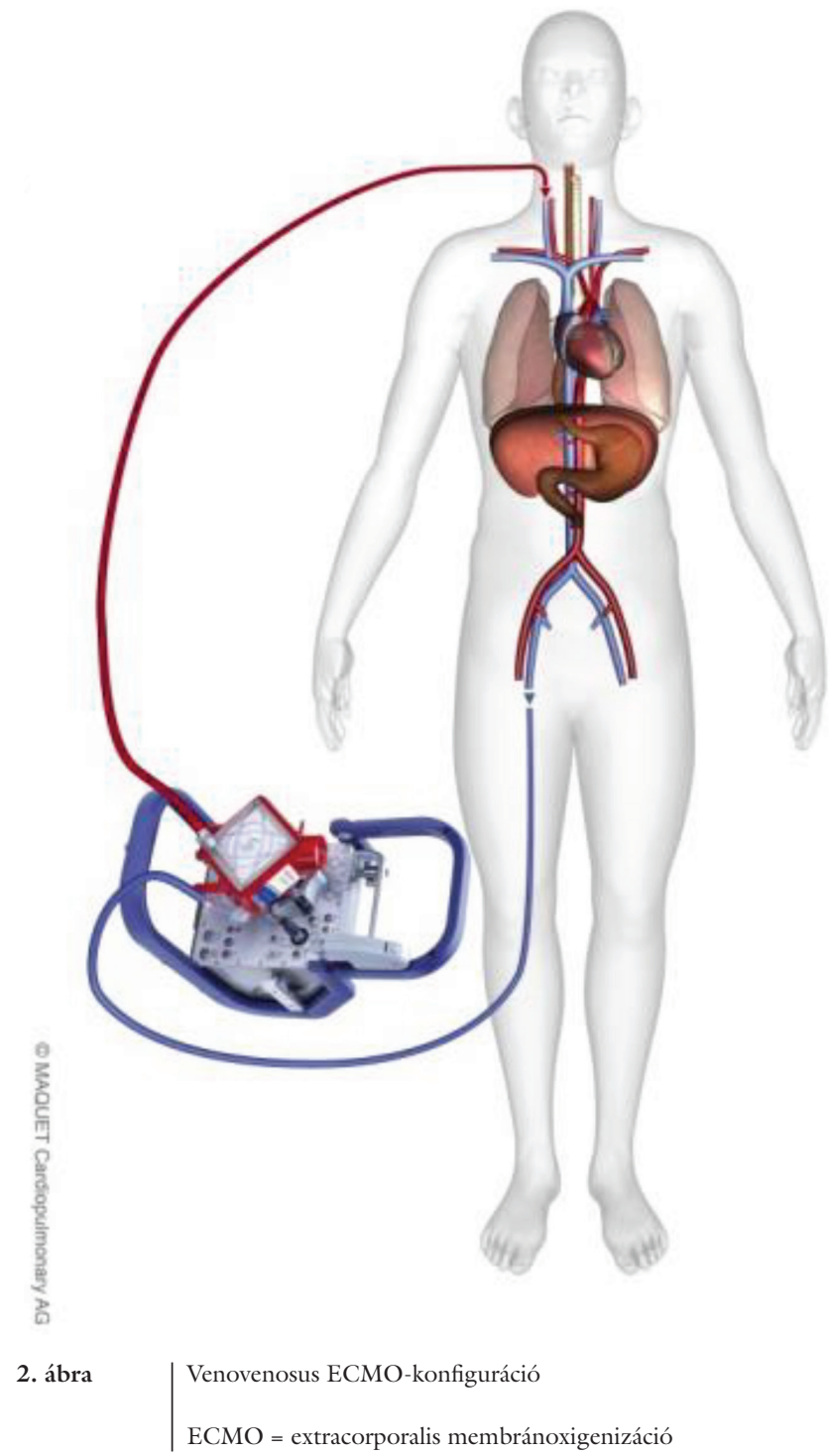

(mely magában foglalta a mentő ECMO-kezelést is) nem javította a 60 napos túlélést. Ugyanakkor a vizsgálat másodlagos végpontja, a terápia sikertelensége (mely az ECMO-csoportban az elhalálozást, a kontrollcsoportban pedig az elhalálozást és a mentő ECMO-kezelést jelentette) szignifikánsan kisebb számban fordult elő az ECMO-csoportban [9]. A CESAR- és az EOLIA-vizsgálat eredményeit metaanalízisben összesítve már szignifikáns különbség mutatkozik a 60 napos halálozásban is az ECMO-csoport javára [10]. A jelenleg zajló COVID19-pandémia során történő ECMO-kezelések tapasztalatai szintén jelentősen növelni fogják ismereteinket.

A súlyos hypoxaemia megszüntetése életet menthet, azonban az extracorporalis szén-dioxid-eltávolításnak is nagy jelentősége lehet a klinikai gyakorlatban. Egyrészt elősegítheti a súlyos és középsúlyos ARDS-ben szenvedő betegek ún. tüdőprotektív, sőt „ultraprotektív” lélegeztetését a belégzési volumenek akár $4 \mathrm{ml} / \mathrm{kg}$-ra (IBW: ideális testsúlyra vonatkoztatva) csökkentésével, másrészt egy másik betegcsoportban, a krónikus tüdőbeteg- 
ségben szenvedő betegek körében segíthet az invazív gépi lélegeztetést elkerülni vagy időtartamát jelentősen lerövidíteni, vagy a tüdőtranszplantációra való várakozás idejét áthidalni [11-16].

A vvECMO-kezelés indikációit az 1. táblázat tartalmazza [17, 18]. Az ECLS-alkalmazás ellenjavallatainak köre nem kiforrott, a legtöbb esetben az elbírálás a betegre szabottan történik. Vannak azonban helyzetek, amikor elöre lehet tudni, hogy a kimenetel nagyon rossz lesz, és ezen az ECMO-alkalmazás sem javíthat (2. táblázat). Score-rendszerek segíthetnek a döntéshozatalban, melyek még az ECMO-indítás előtt lehetővé teszik a prognózis megítélését, ilyen az ún. RESP-score is [19].

A továbbiakban azt szeretnénk bemutatni, hogy intézetünkben hogyan indítottuk el az ECMO alkalmazását, és milyen eredményeket értünk el az első években.

\section{Módszer}

\section{Saját ECMO-programunk megszervezése}

A felkészülést az extracorporalis légzéstámogatás bevezetésére 2015-ben kezdtük meg, bár első próbálkozásunk 2009-ben, a H1N1-járvány alatt történt. 2015 februárjában a londoni Guy’s and St Thomas' Hospital súlyos légzési elégtelenségben szenvedő betegeket ellátó intenzív osztályára szerveztünk tanulmányutat. Ez az osztály az Egyesült Királyság öt vvECMO-centrumának egyike. Itt a technikai részletek és a klinikai ellátás szempontjai mellett a szervezési folyamatokkal is megismerkedtünk. 2015 áprilisában kezdtük meg az eszközök beszerzését (Cardiohelp; Getinge AB, Solna, Svédország), és májusban zajlott az ECMO-team (nővérek és orvosok) klinikánkon zajló képzése. Ezzel párhuzamosan júniusban benyújtottuk a többletkapacitás iránti kérelmünket, melyre az engedélyt a következő évben megkaptuk. Kidolgoztuk intézetünk vvECMO-protokollját, ebben rögzítettük a beavatkozás indikációit, a végiggondolandó relatív ellenjavallatok körét, a szükséges előkészületeket, a kanülálás és a vvECMO-kezelés indításának részleteit, valamint ezen betegek speciális orvosi, ápolási és

1. táblázat A vvECMO javallatai légzési elégtelenségben (az 'ELSO Guidelines for Adult Respiratory Failure' alapján)

\begin{tabular}{l}
\hline vvECMO megfontolandó, ha a halálozási rizikó nagyobb, mint $50 \%$ : \\
$\mathrm{PaO}_{2} / \mathrm{FiO}_{2}<150, \mathrm{FiO}_{2}>90 \%$ és/vagy a LIS-score $2-3$ \\
(legalább 6 órája tartó optimális ellátás mellett) \\
\hline vvECMO indikált, ha a halálozási rizikó nagyobb, mint $80 \%$ : \\
$\mathrm{PaO}_{2} / \mathrm{FiO}_{2}<100, \mathrm{FiO}_{2}>90 \%$ és/vagy a LIS-score 3-4 \\
(legalább 6 órája tartó optimális ellátás mellett) \\
\hline Súlyos $\mathrm{CO}_{2}$-retenció ( $\left.\mathrm{pH}<7,2\right)$ \\
(gépi lélegeztetés és 30 vízcm feletti Pplat mellett) \\
Bronchopleuralis összeköttetés nagy áteresztéssel
\end{tabular}

$\mathrm{FiO}_{2}=$ belégzett oxigénkoncentráció; LIS = lung injury score; $\mathrm{PaO}_{2}=$ parciális oxigénnyomás az artériás vérben; Pplat = platónyomás; $\mathrm{vvECMO}=$ venovenosus extracorporalis membránoxigenizáció
2. táblázat $\mid$ A vvECMO relatív ellenjavallatai légzési elégtelenségben (az 'ELSO Guidelines for Adult Respiratory Failure' alapján)

7 napnál hosszabb gépi lélegeztetés magas $\mathrm{FiO}_{2}(>80 \%)$ és Pplat (>30 vízcm) mellett

Végstádiumú szívbetegség, mely nem alkalmas transzplantációra

Végstádiumú krónikus tüdőbetegség, mely nem alkalmas transzplantációra

Előrehaladott malignus daganatos betegség

Súlyos, progresszív krónikus betegség cachexiával

Súlyos többszervi elégtelenség

Súlyos központi idegrendszeri károsodás

Központi idegrendszeri vérzés, mely a közelmúltban alakult ki, vagy növekszik

Szemtanú nélküli szívmegállás

30 percnél hosszabb CPR dokumentált tudatvisszatérés nélkül

Súlyos immunszuppresszió (abszolút neutrofilszám $<400 / \mathrm{mm}^{3}$ )

A közelmúltban felfedezett hematológiai malignus betegség

30 napon belüli szervtranszplantáció

Csontvelötranszplantált beteg

Elörehaladott HIV

$\mathrm{CPR}=$ cardiopulmonalis resuscitatio $; \mathrm{FiO}_{2}=$ belégzett oxigénkoncent ráció; HIV = humán immundeficientia-virus; Pplat = platónyomás; vvECMO = venovenosus extracorporalis membránoxigenizáció

monitorozási szempontjait. Emellett megbeszéltük és megszerveztük a társszakmákkal (Országos Vérellátó Szolgálat, kardiológia, szívkatéteres laboratórium, szívsebészet, érsebészet, radiológia) való együttmúködés részleteit.

Az első súlyos, refrakter hypoxaemiás légzési elégtelenségben szenvedő beteg kezelésére 2016 áprilisában került sor. 2017 novemberében a Szegedi Intenzíves Találkozó keretében vvECMO-tanfolyamot szerveztünk, külföldi előadók részvételével. Az első cardialis támogatást 2018 márciusában végeztük. A folytatást 2018-ban a folyamatos képzés jelentette, valamint az újabb, tapasztalt centrumokba (Royal Papworth Hospital, Cambridge; Royal Brompton Hospital, London; Országos Onkológiai Intézet, Budapest; Városmajori Szív- és Érgyógyászati Klinika, Budapest) tett tanulmányutak. 2019 áprilisában valósult meg az első mütői alkalmazás tervezett trachearekonstrukció során (vvECMO), 2019 augusztusában pedig az első vaECMO-támogatás akut myocardialis infarctus, cardiogen shockban.

\section{Eredményeink}

Az eltelt évek során összesen 14 beteg esetében használtunk ECMO-t ( 8 férfi, 6 nő, életkor 51 × 15, 20-76 év, APACHE II. score $24 \pm 7$ ). A beavatkozásokhoz 13 alkalommal Cardiohelp (Getinge AB, Solna, Svédország), egy alkalommal LivaNova (LivaNova PLC, London, Egyesült Királyság) rendszert használtunk. A javallat 9 
esetben súlyos refrakter hypoxaemiás légzési elégtelenség, I esetben tracheooesophagealis fistula és légzési elégtelenség, l esetben mütét alatti légzéstámogatás tervezett trachearekonstrukció során és 3 beteg esetében cardiogen shock volt. Az ECMO 11 betegben a légzés, 3 betegben a keringés támogatását szolgálta, 13 esetben venovenosus, l esetben venoarteriosus konfigurációban.

A súlyos refrakter hypoxaemiás légzési elégtelenség oka 8 esetben közösségben szerzett, 1 esetben kórházban szerzett pneumonia, 1 esetben choriocarcinoma tüdőinfiltrációja volt. A tüdőgyulladást 7 betegben influenzavírus okozta, előfordult még invazív aspergillosis, cytomegalovirus, Pneumocystis okozta infekció és tuberkulózis. A betegek lélegeztetése az ECMO-kezelés megkezdése előtt a tüdő protektív lélegeztetési stratégia szerint történt, mentő beavatkozásként 5 betegnél APRV- (airway pressure release ventilation) üzemmóddal, 9 betegnél hasra fordítással is próbálkoztunk. A tüdőkárosodás súlyosságát leíró 'lung injury score' 3,1 \pm 0,4 volt, ez 80\%-nál nagyobb halálozási rizikót jelent.

A refrakter szív- és keringési elégtelenség 2 betegben aortadissectio mütéti megoldása során fellépő cardiogen shock, l esetben akut myocardialis infarctus cardiogen shock következményeképpen alakult ki. A két, postcardiotomiás cardiogen shock esetében jobbszívfél-elégtelenség miatt volt lehetetlen leválasztani a betegeket a cardiopulmonalis bypassról, ezért döntöttünk extracorporalis jobbszívfél-támogatás mellett.

A kanülálás mindig percutan módon történt az intenzív osztályon ultrahangvezérléssel, kivéve a postcardiotomiás eseteket, amelyeknél centrálisan, sebészileg kerültek a kanülök behelyezésre a szívmütőben. A légzéstámogatásra használt vvECMO-k esetében mindig a femoro-jugularis utat követtük, azaz a „kivevo”” kanül a jobb oldali v. femoralison át a v. cava inferiorba, a „visszaadó” kanül pedig a jobb oldali v. jugularis internán keresztül a jobb pitvar magasságában került felvezetésre. A két, jobbszívfél-támogatás céljából végzett ECMO esetében a kanülök a szívmütétek során lettek behelyezve a jobb pitvarba („kivevo”") és az arteria (a.) pulmonalisba („viszszaadó”). A vaECMO-hoz a kanülálás szintén a szívmútőben történt, a jobb oldali a. és v. femoralison keresztül, sebészileg. Az antikoagulálást ACT-vezérelten végeztük, nem frakcionált heparin folyamatos adásával, a céltartomány 160-180 másodperc volt.

Betegeinket mindig intenzív osztályos, ECMO-képzésben részesült szakápoló látta $\mathrm{el}, \mathrm{l}$ beteg : 1 nővér arányban, egy alkalommal pumpatechnikusok segítségével. A megszokott paramétereken kívül folyamatosan monitoroztuk az ECMO-pumpa fordulatszámát, a véráramlást, a gázáramlást, a „kivevő” és a „visszaadó” szár nyomását, a transzmembrán nyomást (delta-P). Ezenkívül a folyamatosan monitorozott v. cava inferior oxigénszaturáció és a rendszeres artériásvérgáz-vizsgálatok mellett naponta megnéztük a pre- és posztoxigenátor vérgázokat a membrántüdő állapotának felmérésére.
A légzéstámogatások esetén, amikor a nyugalmi lélegeztetőgép-beállítások mellett már $6 \mathrm{ml} / \mathrm{kg}$ (IBW) körüli légzési volumenek megjelentek, naponta 100\% $\mathrm{FiO}_{2}$-tesztet végeztünk, a lélegeztetőgépen 100\%-ra állítva az oxigénkoncentrációt, és amennyiben így a $\mathrm{PaO}_{2}$ $225 \mathrm{Hgmm}$ felett volt, elkezdtük az vvECMO-ról történő leszoktatást. A cardialis támogatások esetén, amikor a gyógyszeres támogatás (adrenalin, noradrenalin, milrinon) jelentősen csökkenthető volt, szintén mérlegeltük az ECLS-ról való leszoktatást. A leszoktatás légzéstámogatás esetén az ECMO-véráramlás 31 /min-re való csökkentésével, majd a 'sweep' gázáramlás fokozatos csökkentésével és leállításával történt, rendszeres vérgázvizsgálatok és a légzési mechanika monitorozása mellett. A cardialis támogatásról való leszoktatás során az ECMO-véráramlást csökkentettük fokozatosan 11 /minig, folyamatos invazív hemodinamikai monitorozás és echocardiographiás ellenőrzés mellett. Amennyiben a leszoktatási kísérlet sikeres volt, és a beteg stabil maradt, a dekanülálás perifériás vvECMO esetében az intenzív osztályon, centrális kanülálás esetén a szívmútőben történt.

Az ECMO-támogatás ideje légzéstámogatás esetében $14 \pm 6$ nap, a cardialis támogatások esetében $5 \pm 4$ nap volt. A 10, hypoxaemiás légzési elégtelenségben szenvedő beteg közül 6 esetben keringési elégtelenség, 6 esetben vesepótló kezelést igénylő akut vesekárosodás, 2 esetben súlyos májelégtelenség is kialakult. A szívelégtelen betegek közül kettőnek szintén volt akut vesekárosodása, egyiküknek májelégtelensége és lélegeztetéssel összefüggő tüdőgyulladása is.

Az ECMO-kezeléssel összefüggő szövődmények közül a vérzések voltak a leggyakoribbak: 9 esetben tapasztaltunk jelentősebb vérzést, ezek között központi idegrendszert érintő nem volt. Jelentős haemolysis, a kanülálással összefüggő infekció vagy végtagkeringési zavar nem fordult elő. A kanülök eltávolítását követően minden esetben végeztünk Doppler-ultrahangvizsgálatot, 3 betegnek alakult ki mélyvénás thrombosisa. Az intenzív osztályos ápolási idő $27 \pm 13$, illetve $21 \pm 17$ nap volt a két betegcsoportban. 9 beteget jó funkcionális állapotban bocsátottunk el, 5 beteg halt meg osztályunkon, további 3 később, a kórházi bennfekvés során.

\section{Megbeszélés}

ECLS-program indításához komoly intézményi, multidiszciplináris és személyes elkötelezettség szükséges. Nemcsak az eszközök költségei igen magasak, hanem maga a beavatkozás és az alkalmazás ideje alatti monitorozás és ellátás is igen összetett, nagy tudás-, eszköz- és személyzetigényű. A felkészülésben és az indulásban tapasztalt ECMO-centrumokkal való együttmúködés nyújtja a legnagyobb segítséget. A megfelelő gyakorlat elősegítésére az ELSO (Extracorporeal Life Support Organization) ajánlásokat fogalmazott meg mind a neonatalis, mind a gyermek, mind a felnőtt keringési és lég- 
zési elégtelenség támogatásának esetére [20]. Az intézményi és szervezeti feltételekre vonatkozó javaslatokat tartalmazza az 'ELSO Guidelines for ECMO Centers' [21, 22], intézetünkben ezt az irányelvet igyekeztünk követni. E szerint ECMO-centrum létesítése olyan nagy, tercier központokban javasolt, melyek rendelkeznek neonatalis, gyermek és felnőtt intenzív osztályokkal, és legalább évi 6 beteg ECLS-támogatására van kilátás. Az ECMO-teamet egy erre megfelelő képzettséggel rendelkező, erre a feladatra kijelölt orvos vezeti. Ő a felelős a program gyakorlati megvalósításáért, valamint a munkában részt vevők képzéséért és megfelelő továbbképzéséért, továbbá az ELSO irányában az adatszolgáltatásért is. $\mathrm{Az}$ ECMO-team további tagjai képzésben részesült orvosok és nővérek, közülük egy tölti be a koordinátor szerepét. Az orvosok között a helyi igényeknek megfelelően kell lennie intenzív terápiás szakembernek, aneszteziológusnak és az alkalmazási profil szerint kardiológusnak, szívsebésznek és gyermekgyógyásznak. Szükséges lehet ezenkívül az érsebészekkel, mellkassebészekkel, pulmonológusokkal és radiológusokkal, továbbá a sürgősségi osztállyal való szoros együttmúködés. Az ECMO-képzésben részesült nővérek munkáját sok centrumban pumpatechnikusok segítik. A nővér : beteg arány a 2 : 1-tól az 1 : 2-ig terjed - mi az 1 beteg : 1 nővér arányt tudjuk biztosítani. Az intézménynek ezenkívül megfelelő és rendszeresen felújított ellátási protokollal kell rendelkeznie a kívánt ELSO-alkalmazási területen. Biztosítani kell mindezek mellett a folyamatos laboratóriumi, vérellátói, radiológiai és szívsebészeti hátteret. Végül, meg kell teremteni ezen betegek kórházon belüli és kórházak közötti szállításának feltételeit; ebből jelenleg a kórházon belüli mozgatás feltételei adottak, más centrumba történő szállítás az Országos Mentőszolgálat és a fogadó intézmény együttmúködésével lehetséges. A megfelelő rehabilitáció és utánkövetés szintén fontos a sikeres ECMO-program múködtetéséhez, mivel sokszor a betegek az intenzív osztályról való kiadás után is még sokáig ellátásra és segítségre szorulnak.

Nagy jelentőségú az ECMO-team folyamatos elméleti és gyakorlati képzése. Intézetünkben ezt nagy tapasztalattal rendelkező centrumokba történő tanulmányutakkal, kongresszusi részvételekkel, rendszeres megbeszélésekkel, cikkreferálásokkal és vízkörös gyakorlással igyekszünk elérni. Ennek köszönhetően eredményeink a jó életminőséggel való túlélés tekintetében az alacsony esetszám ellenére is hasonlóak a nemzetközi adatokhoz.

Az extracorporalis szervtámogató technikák alkalmazása komoly szakmai, etikai dilemmákat vethet fel, ezért szükséges alapos átgondolás és megfontolt interdiszciplináris döntés a kezelés megkezdéséről [23]. A beavatkozás rendkívül költséges, rizikó-haszon profilja több szituációban nincs jól körülírva. A komplikációk száma - fơként nagy vérzések, érsérülés, distalis végtagischaemia és thrombosis, haemolysis és infekciók előfordu- lása - magas. Gyakran előfordulhat, hogy a beteg felvilágosítására és beleegyezésére nincs lehetőség, ekkor a hozzátartozók részletes tájékoztatására és beleegyezésére van szükség.

Nehéz a megfelelő betegkiválasztás is. Mivel a súlyos hypoxaemiás légzési elégtelenség kivételével kontrollált, randomizált vizsgálatok nem állnak rendelkezésünkre, valamint mivel az alkalmazási terület bővülésével folyamatosan egyre újabb adatok válnak ismertté, az ajánlások is gyakran változnak, és kevéssé határozottan foglalnak állást. A betegkiválasztás így az esetek nagy részében személyre szabottan történik, és még a kontraindikációk köre sem egyértelmú. Az életvégi döntések meghozatala ECMO-n levő beteg esetében talán még a szokásosnál is nehezebb lehet. Komoly etikai dilemmába kerülhetünk az ún „bridge-to-nowhere” szituációban, amikor a beteg tiszta tudattal, stabil állapotban van ECMO-n, alapbetegsége azonban nem gyógyul, és semmilyen további intervencióra nem alkalmas. Emellett nem elhanyagolható probléma, hogy a nagy eszköz- és tudásigényü, költséges technika nem áll mindenütt, mindenki rendelkezésére, még a fejlett egészségüggyel rendelkező országokban sem, így nem biztosítható az egyenlő hozzáférés esélye. Ezt a nehézséget több ország regionális ECMO-centrumok létrehozásával, standardizált referálási protokollok kialakításával és a kritikus ellátási igényü, ECMO-várományos vagy már ECMO-n levő betegek hozzáértő, biztonságos szállításának megszervezésével próbálja megoldani.

\section{Következtetés}

Eredményeink azt támasztják alá, hogy az ECMO-alkalmazás egy átfogó program keretében Magyarországon is megvalósítható lehetne regionális centrumokban, olyan betegek számára, akiknél a nyereség várhatóan nagy, és e nélkül a beteg gyógyulási esélyei minimálisak. További jelentőségét adja a módszernek a koronavírus-betegségben kialakuló súlyos pneumoniák várható előfordulása a jövőben is. Hazánkban a vvECMO-támogatás jelenleg az Országos Onkológiai Intézet Intenzív Osztályán és intézetünkben érhető el [24, 25], a közeljövőben viszont több helyen válhat hozzáférhetővé, így fontos lesz, hogy korán felismerjük ezeket a potenciálisan reverzibilis, de ECLS nélkül reménytelen eseteket, és az ellátás összehangolására egységes oktatási, megvalósítási és finanszírozási programot hozzunk létre.

Anyagi támogatás: A szerzők anyagi támogatásban nem részesültek.

Szerzői munkamegosztás: Z. É.: A kézirat elkészítése, a beavatkozások végzése, szervezés és oktatás. R. L.: Oktatás, a kézirat bírálata. B. G., B. I., B. K., Cs. Zs., 
H. P., K. A., L. A., Sz.-B. A.: A kézirat szerkesztése, beavatkozások végzése. M. Zs., B. B.: Oktatás és szervezés. A cikk végleges változatát valamennyi szerző elolvasta és jóváhagyta.

\section{Érdekeltségek: A szerzőknek nincsenek érdekeltségeik.}

\section{Irodalom}

[1] Patroniti N, Bonatti G, Senussi T, et al. Mechanical ventilation and respiratory monitoring during extracorporeal membrane oxygenation for respiratory support. Ann Transl Med. 2018; 6: 386

[2] Fan E, Gattinoni L, Combes A, et al. Venovenous extracorporeal membrane oxygenation for acute respiratory failure: a clinical review from an international group of experts. Intensive Care Med. 2016; 42: 712-724.

[3] Extracorporeal Life Support Organization. ECLS registry report, international summary. July, 2020. Available from: https:// www.elso.org/Registry/Statistics/InternationalSummary.aspx [accessed: August 8, 2020].

[4] Australia and New Zealand Extracorporeal Membrane Oxygenation (ANZ ECMO) Influenza Investigators, Davies A, Jones D, Bailey M, Beca J, et al. Extracorporeal membrane oxygenation for 2009 influenza $\mathrm{A}(\mathrm{H} 1 \mathrm{Nl})$ acute respiratory distress syndrome. JAMA 2009; 302: 1888-1895.

[5] Noah MA, Peek GJ, Finney SJ, et al. Referral to an extracorporeal membrane oxygenation center and mortality among patients with severe 2009 influenza A(H1N1). JAMA 2011; 306: 16591668.

[6] Pham T, Combes A, Rozé H, et al. Extracorporeal membrane oxygenation for pandemic influenza $\mathrm{A}(\mathrm{HlNl})$-induced acute respiratory distress syndrome: a cohort study and propensitymatched analysis. Am J Respir Crit Care Med. 2013; 187: 276285.

[7] Napolitano LM, Park PK, Raghavendran K, et al. Nonventilatory strategies for patients with life-threatening $2009 \mathrm{HINl}$ influenza and severe respiratory failure. Crit Care Med. 2010 38(Suppl): e74-e90.

[8] Peek GJ, Mugford M, Tiruvoipati R, et al. Efficacy and economic assessment of conventional ventilatory support versus extracorporeal membrane oxygenation for severe adult respiratory failure (CESAR): a multicentre randomised controlled trial. Lancet 2009; 374: 1351-1363

[9] Combes A, Hajage D, Capellier G, et al. Extracorporeal membrane oxygenation for severe acute respiratory distress syndrome. N Engl J Med. 2018; 378: 1965-1975.

[10] Munshi L, Walkey A, Goligher E, et al. Venovenous extracorporeal membrane oxygenation for acute respiratory distress syndrome: a systematic review and meta-analysis. Lancet Respir Med. 2019; 7: 163-172.

[11] Terragni PP, Del Sorbo L, Mascia L, et al. Tidal volume lower than $6 \mathrm{ml} / \mathrm{kg}$ enhances lung protection: role of extracorporeal carbon dioxide removal. Anesthesiology 2009; 111: 826-835.

[12] Bein T, Weber-Carstens S, Goldmann A, et al. Lower tidal volume strategy (approximately $3 \mathrm{ml} / \mathrm{kg}$ ) combined with extracorporeal $\mathrm{CO}_{2}$ removal versus 'conventional' protective ventilation $(6 \mathrm{ml} / \mathrm{kg})$ in severe ARDS: the prospective randomized Xtraventstudy. Intensive Care Med. 2013; 39: 847-856.

[13] Fanelli V, Ranieri MV, Mancebo J, et al. Feasibility and safety of low-flow extracorporeal carbon dioxide removal to facilitate ultra-protective ventilation in patients with moderate acute respiratory distress syndrome. Crit Care 2016; 20: 36.

[14] Combes A, Fanelli V, Pham T, et al. Feasibility and safety of extracorporeal $\mathrm{CO}_{2}$ removal to enhance protective ventilation in acute respiratory distress syndrome: the SUPERNOVA study. Intensive Care Med. 2019; 45: 592-600.

[15] Braune S, Sieweke A, Brettner F, et al. The feasibility and safety of extracorporeal carbon dioxide removal to avoid intubation in patients with COPD unresponsive to noninvasive ventilation for acute hypercapnic respiratory failure (ECLAIR study): multicentre case-control study. Intensive Care Med. 2016; 42: 14371444 .

[16] Morelli A, Del Sorbo L, Pesenti A, et al. Extracorporeal carbon dioxide removal $\left(\mathrm{ECCO}_{2} \mathrm{R}\right)$ in patients with acute respiratory failure. Intensive Care Med. 2017; 43: 519-530.

[17] Extracorporeal Life Support Organization (ELSO). Guidelines for adult respiratory failure. August, 2017. Available from: https://www.elso.org/Portals/0/ELSO\%20Guidelines\%20 For\%20Adult\%20Respiratory\%20Failure\%201_4.pdf [accessed: August 8, 2020].

[18] Brodie D, Slutsky AS, Combes A. Extracorporeal life support for adults with respiratory failure and related indications: a review. JAMA 2019; 322: 557-568.

[19] Schmidt M, Bailey M, Sheldrake J, et al. Predicting survival after extracorporeal membrane oxygenation for severe acute respiratory failure. The Respiratory Extracorporeal Membrane Oxygenation Survival Prediction (RESP) score. Am J Respir Crit Care Med. 2014; 189: 1374-1382.

[20] Extracorporeal Life Support Organization (ELSO). Guidelines for adult cardiac failure. December, 2013. Available from: https://www.elso.org/Portals/0/IGD/Archive/FileManager/e76ef78eabcusersshyerdocumentselsoguidelinesforadultcardiacfailure 1.3.pdf [accessed: August 8, 2020].

[21] Extracorporeal Life Support Organization (ELSO). Guidelines for ECMO Centers. March, 2014. Available from: https:// www.elso.org/Portals/0/IGD/Archive/FileManager/faf3f6a3 c7cusersshyerdocumentselsoguidelinesecmocentersv1.8.pdf [accessed: August 8, 2020].

[22] Combes A, Brodie D, Bartlett R, et al.; the International ECMO Network (ECMONet). Position paper for the organization of extracorporeal membrane oxygenation programs for acute respiratory failure in adult patients. Am J Respir Crit Care Med. 2014; 190: 488-496.

[23] Riggs KR, Becker LB, Sugarman J. Ethics in the use of extracorporeal cardiopulmonary resuscitation in adults. Resuscitation 2015; 91: 73-75.

[24] Madurka I, Bartók T, Kormosói-Tóth K, et al. Successful extracorporeal membrane oxygenation (ECMO) treatment in Legionella pneumonia. [Sikeres extracorporalis membránoxigenizációs (ECMO) kezelés Legionella-pneumoniában.] Orv Hetil. 2019; 160: 235-240. [Hungarian]

[25] Madurka I, Elek J, Kocsis Á, et al. Experiences with venovenous extracorporeal membrane oxygenation (ECMO) support for thoracic surgery in Hungary. Retrospective clinical study. [Venovenosus extracorporalis membránoxigenizációval (ECMO) végzett mellkassebészeti mútétek tapasztalatai Magyarországon. Retrospektív klinikai tanulmány.] Orv Hetil. 2019; 160: 16551662. [Hungarian]

(Zöllei Éva dr., Új Klinika, AITI Titkárság, Szeged, Semmelweis u. 6., 6725 e-mail: zollei@hotmail.com)

A cikk a Creative Commons Attribution 4.0 International License (https://creativecommons.org/licenses/by/4.0/) feltételei szerint publikált Open Access közlemény, melynek szellemében a cikk bármilyen médiumban szabadon felhasználható, megosztható és újraközölhető, feltéve, hogy az eredeti szerző és a közlés helye, illetve a CC License linkje és az esetlegesen végrehaitott módosítások feltüntetésre kerülnek. (SID_1) 